proposed that a list of ophthalmic medical practitioners qualified and willing to see insured members of approved societies should be prepared in accordance with the following principles. Anyone desiring to join in the scheme will have to furnish evidence $(a)$ that he has held hospital or other appointments affording special opportunities for acquiring special skill and experience of the kind required for the performance of the service rendered, and has had actual recent practice in performing the service rendered or services of a similar character; or (b) that he has had special academic or post-graduate study of a subject which comprises the service, rendered, and has had actual recent practice as aforesaid; or $(c)$ that he is generally recognized by other practitioners in the area as having special proficiency and experience in a subject which comprises the service rendered."

\title{
ANNOTATIONS
}

\section{Cranial Artefacts}

In an article (Rev. gén. d'Ophtal., March, 1924), dealing with a case of oxycephaly, Cosmettatos, of Athens, makes a remarkable statement of a custom in Greece which is probably unknown to the majority of readers of this journal. The paragraph is the following : "The history and the typical symptomatology of our patient exclude the hypothesis that the abnormal form of the skull is to be attributed to an artificially brought about deformity. This custom is fairly wide-spread in Greece and especially in Epirus, the custom, namely, of exerting pressure upon the occiput of new-born children so as to produce flattening of the occipital region of the skull." De gustibus non est disputandum. The Chinese, in the past, were accustomed to squeeze the feet of their infants; the modern Greek apparently squeezes the other end of the baby. The Armenians are in the habit of putting a dry cloth round the infant's head and afterwards damping it in order to produce the typical sloping forehead which is characteristic of so many of this race. The shape of the skulls depicted on ancient Hittite monuments shows similar characteristics, and may have been produced in the same way, since the Armenians are usually regarded as descended from this race.

\section{Refraction in General Practice}

In the British Medical Journal for December 6, 1924, is an article by Dr. MacRae, of Corbridge-on-Tyne, on this subject ; and a very good article it is.

As soon as anyone is qualified there is nothing to stop him or her from setting up as an oculist. There is no reason why any who 